\title{
Mirosław Wlodarczyk
}

Społeczna Wyższa Szkoła Przedsiębiorczości

i Zarządzania w Łodzi

Jerzy Janczewski

Akademia Humanistyczno-Ekonomiczna

w Łodzi

\section{Warsztaty samochodowe w warunkach globalizacji}

W Polsce w ostatnim 20-leciu notuje się dynamiczny rozwój branży motoryzacyjnej. Jesteśmy krajem, który w sektorze motoryzacyjnym przyciągnął wielkie inwestycje ${ }^{1}$ zagraniczne, dzięki czemu sektor ten stał się jedną z kluczowych gałęzi przemysłu pod względem wartości produkcji, zatrudnienia, nakładów inwestycyjnych i udziału w eksporcie.

Dynamikę rozwoju branży motoryzacyjnej ostatnich lat zawdzięczamy m.in. konkurencji w stosowaniu nowych technologii. Ten swoisty wyścig był wielkim wyzwaniem dla producentów. Ponadto ciągle rosnące wymogi związane $\mathrm{z}$ ochroną środowiska naturalnego oraz stałe podnoszenie poziomu bezpieczeństwa czynnego i biernego samochodów sprawiły, iż branża motoryzacyjna została zaliczona do najbardziej innowacyjnych gałęzi przemysłu (Olszowski, Olszewska, Jastrzębska 2009, s. 4).

Lata 90. XX w. i początek XXI w. charakteryzują się również dużymi zmianami na rynku samochodów. W ciągu 20 lat liczba zarejestrowanych pojazdów samochodowych w Polsce wzrosła niemal 2,5-krotnie, a w Unii Europejskiej jesteśmy na szóstym miejscu pod względem liczby zarejestrowanych samochodów. Użytkujemy samochody o coraz większym zaawansowaniu technologicznym, a z naszych dróg prawie całkowicie zniknęły popularne niegdyś Polonezy, Fiaty 126 i 125, Żuki, Nysy i Tarpany.

Oprócz zmian na rynku samochodów rozwój branży motoryzacyjnej implikuje zmiany na rynku usług serwisowych i na rynku części zamiennych. Samochód nie wystarczy tylko wyprodukować; aby spełniał swoje zadanie, musi być prawidłowo serwisowany. Stawia to przed warsztatami ciągle nowe wyzwania. Od warsztatów wymaga się uzupełniania specjalistycznej wiedzy nie tylko mechanicznej, ale również z zakresu elektrotechniki i elektroniki samochodowej. Warsztaty muszą szybko i trafnie diagnozować występujące usterki oraz przeprowadzić naprawę zgodnie z procedurami zalecanymi przez producenta. Rośnie też zapotrzebowanie na specjalistyczną informację techniczną związaną z serwisowaniem poszczególnych modeli i marek samochodów, a wyposażenie samochodów w dużą liczbę wzajemnie powiązanych ze sobą systemów stwarza coraz więcej nowych problemów.

\footnotetext{
${ }^{1}$ Według danych Ministerstwa Gospodarki z 2008 r., inwestycje firm z branży motoryzacyjnej w specjalnych strefach ekonomicznych wyniosły 16 mld zł, czyli 33\% ogólnych nakładów inwestycyjnych w Polsce.
} 


\section{Samochody w Polsce}

W Polsce z roku na rok wzrasta liczba zarejestrowanych pojazdów samochodowych. Według danych GUS (GUS 2010, s. 378), na dzień 31 grudnia 2000 r. w Polsce było zarejestrowanych 14106 tys. pojazdów z tego 9991 tys. stanowiły samochody osobowe ${ }^{2}$. Natomiast w analogicznym okresie roku 2009 liczba zarejestrowanych pojazdów wynosiła 22025 tys., w tym 16495 tys. samochodów osobowych. W strukturze zarejestrowanych samochodów zarówno w roku 2000, jak i w 2008 dominowały samochody osobowe, stanowiące od 70 do $75 \%$ wszystkich pojazdów. Od 2000 r. do końca 2009 r. przybyło w naszym kraju prawie 7919 tys. pojazdów samochodowych (w tym 6509 tys. samochodów osobowych). Oznacza to, że w latach 2000-2009 z każdym rokiem przybywało średnio około 790 tys. zarejestrowanych po raz pierwszy pojazdów samochodowych (650 tys. samochodów osobowych), w tym nowych, zakupionych w salonach, oraz używanych, sprowadzonych z zagranicy.

W roku 2000 średni wskaźnik motoryzacji w Polsce wynosił 270 samochodów na 1000 mieszkańców i był prawie dwukrotnie niższy od wskaźnika motoryzacji w Niemczech. Obecnie różnica ta jest rzędu $25 \%$, a w przyszłości (2012) powinna być jeszcze mniejsza, gdyż wskaźnik motoryzacji ma tendencję wzrostową (ryc. 1). W Luksemburgu i we Włoszech wskaźnik ten w roku 2007 wynosił około 650 samochodów na 1000 mieszkańców, zaś w Stanach Zjednoczonych około 750 samochodów (GUS 2010, s. 379). W Polsce pomimo dużego przyrostu liczby zarejestrowanych samochodów w ostatnim dziesięcioleciu nadal wskaźnik motoryzacji jest stosunkowo mały, co może świadczyć o dużej potencjalnej chłonności naszego rynku.

Ryc. 1. Wskaźnik motoryzacji - liczba samochodów na 1000 mieszkańców w Polsce i w Niemczech

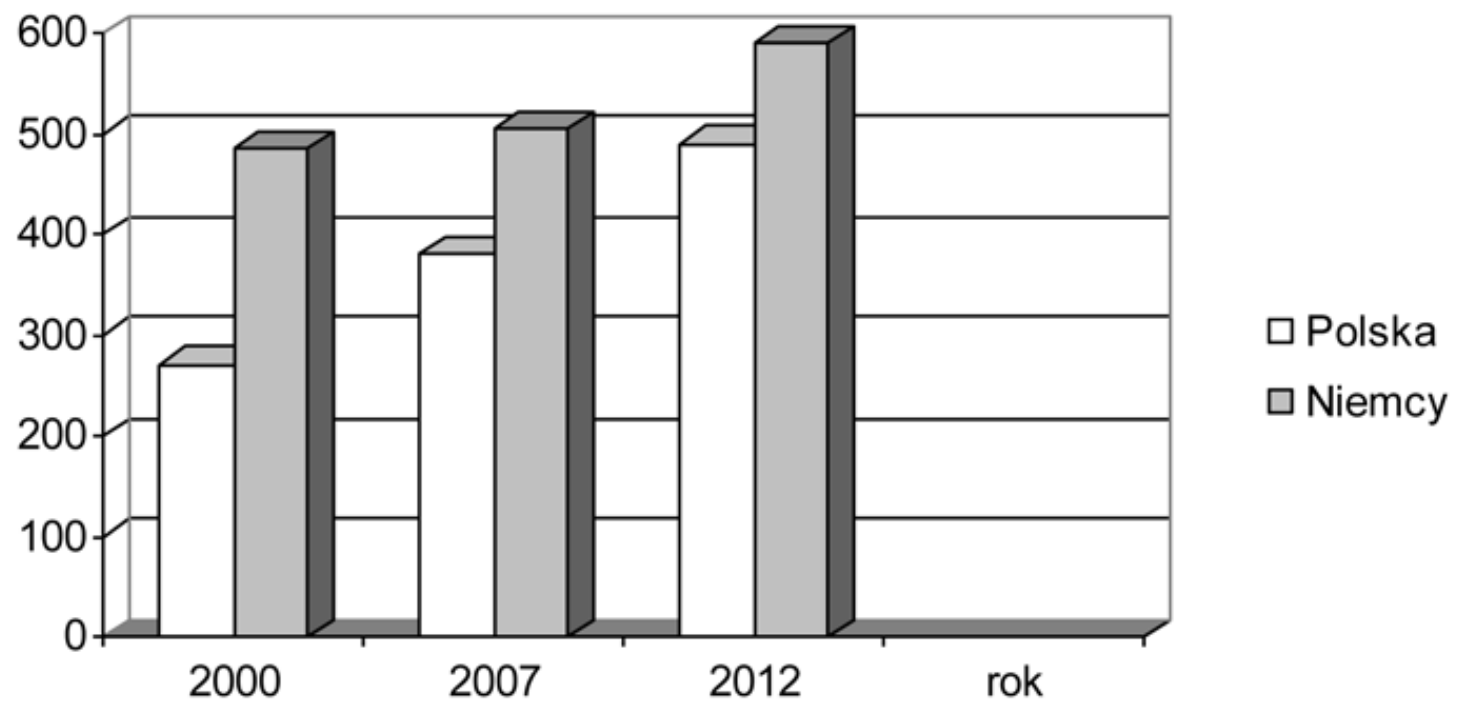

Źródło: opracowanie własne.

W Polsce brakuje systematycznych danych na temat stanu taboru użytkowanych indywidualnie samochodów osobowych obrazujących jego strukturę wiekową i strukturę przebiegu. Pomimo tych trudności można na podstawie danych publikowanych przez różne instytucje i firmy analityczne (Samar, Motofocus) oszacować, że najwięcej użytkujemy samochodów starych - mających powyżej 10 lat (ryc. 2), natomiast marginalną grupę stanowią samochody nowe, do 2 lat, i jest ona równoważna grupie samochodów użytkowanych powyżej 31 lat.

\footnotetext{
${ }^{2}$ Pozostałe to samochody ciężarowe, ciągniki siodłowe, balastowe i rolnicze, autobusy i motocykle.
} 
Jedynie Hiszpania (Koch 2004, s. 59) ma podobną do Polski strukturę wiekową samochodów. W pozostałych, bogatszych krajach Unii, np. w Niemczech, samochody 10-letnie i starsze nie są masowo użytkowane (ryc. 3). Warto zauważyć, że od początku bieżącego stulecia aż do roku 2006 zwiększał się średni wiek samochodu osobowego zarówno w Niemczech, jak i w Polsce, przy czym zjawisko to występowało w Polsce znacznie wyraźniej. Wynikało to z rosnącego w tym okresie importu używanych pojazdów do Polski (ryc. 4) i spadku popytu na nowe samochody w Niemczech.

Ryc. 2. Struktura pojazdów według ich wieku - 2008 r.

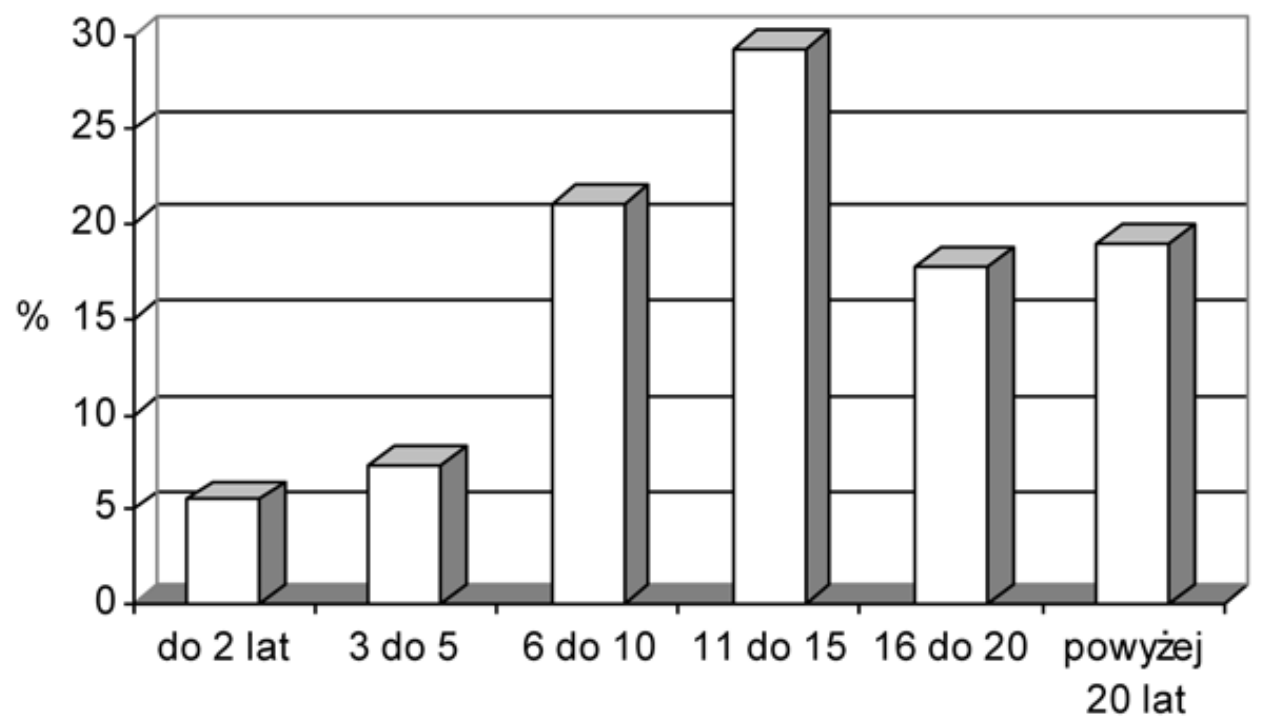

Źródło: opracowanie własne na podstawie danych Instytutu Samar.

Ryc. 3. Średni wiek samochodu osobowego w Polsce i w Niemczech

\section{$\square$ Polska $\square$ Niemcy}

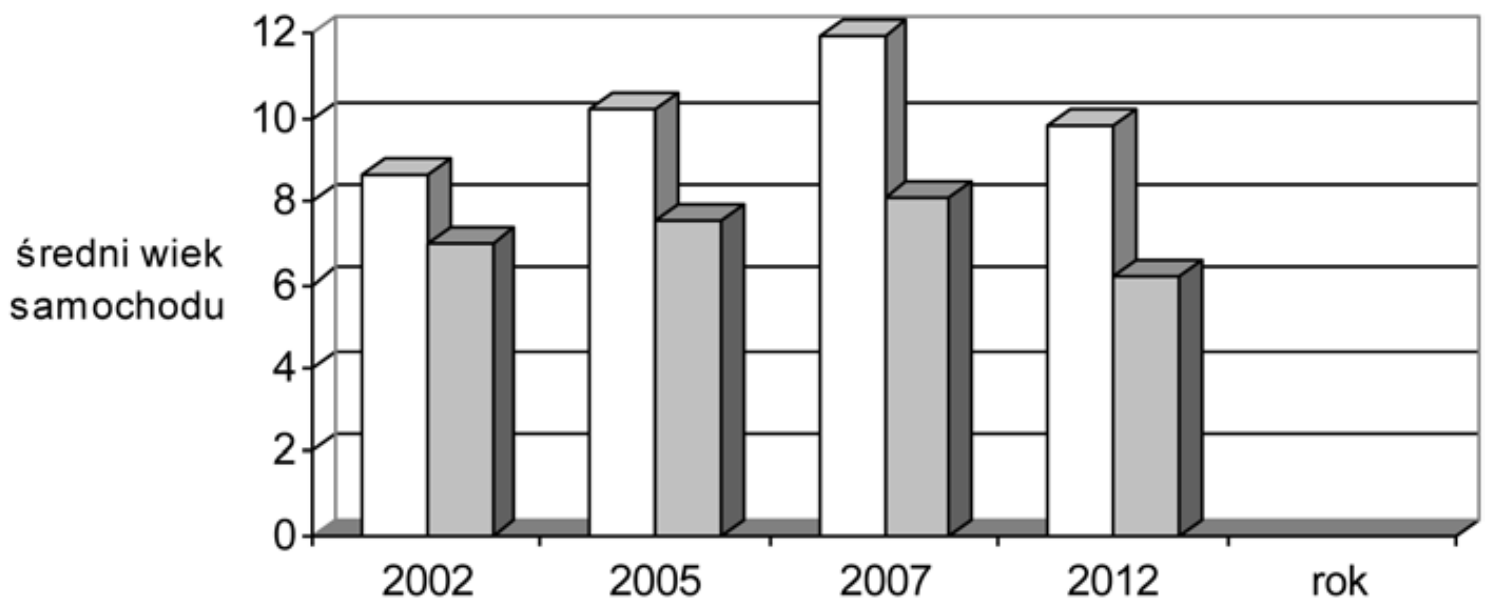

Źródło: opracowanie własne na podstawie Soszyński K., Przyszłość polskich warsztatów, http://www.e-autonaprawa.pl/artykuly/67/przyszlosc-polskich-warsztatow.html (stan na dzień 05.09.2009). 
Ryc. 4. Import samochodów używanych w latach 2005-2009 (sztuki)

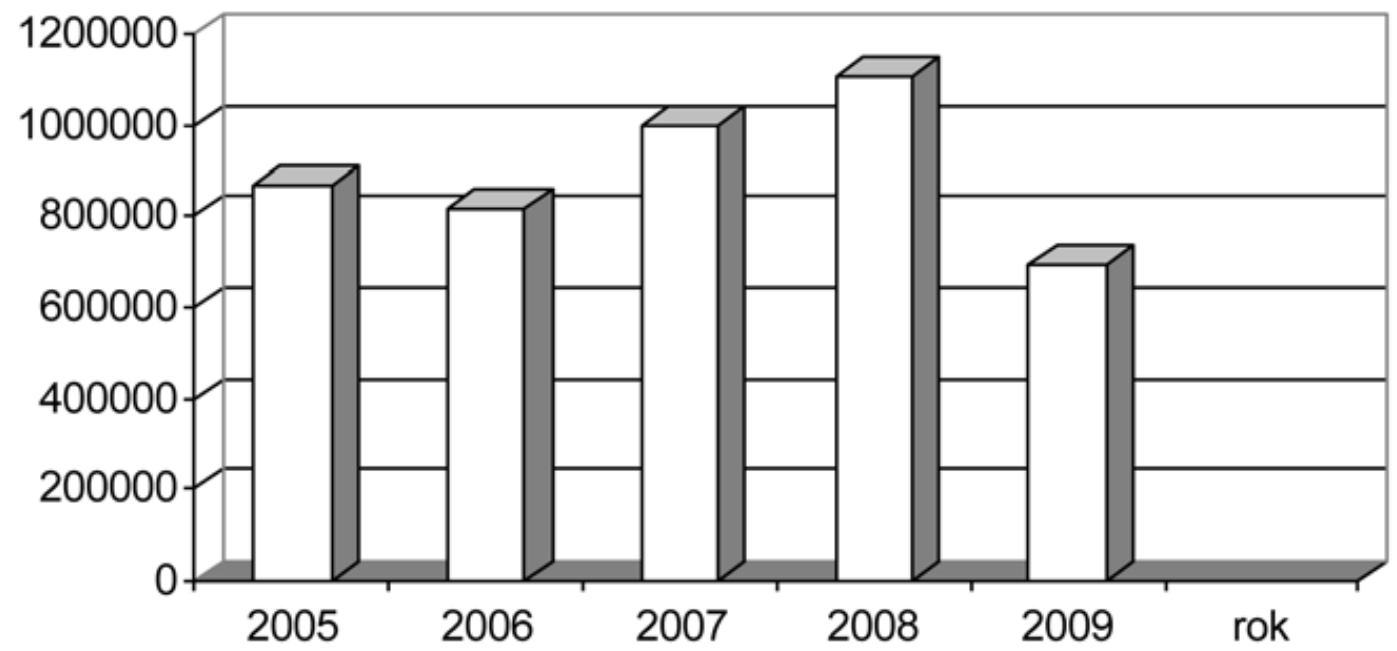

Źródło: opracowanie własne na podstawie danych Instytutu Samar.

W ostatnich latach średni wiek samochodu zmniejszał się zarówno w Polsce, jak i w Niemczech i trend ten powinien występować co najmniej do 2012 r. (Soszyński 2009.09.15; por. ryc. 3). Stosunkowo wysoki wiek samochodów wskazuje, że w najbliższych latach nasz park samochodowy powinien stawać się coraz młodszy prawdopodobnie dzięki importowi samochodów trzy-sześcioletnich i przyrostu sprzedaży nowych. Dla przykładu w marcu 2010 import używanych samochodów w wieku powyżej 10 lat stanowił 42,70\%, od 5 do 10 lat 47,51\%, zaś najmłodszych (do 4 lat) 9,78\%. Natomiast jeszcze w styczniu 2010 r. pojazdy w wieku do 4 lat miały mniejszy udział w imporcie, podczas gdy tych najstarszych było o 3,07\% więcej (Moto Onet.pl, 2010.04.27). Nadal jednak wskaźnik odnowy parku samochodowego - liczony jako stosunek zakupu nowych samochodów do liczby zarejestrowanych - jest w Polsce niewielki, gdyż wynosi zaledwie 2\% i jest 3,5 razy niższy niż średni wskaźnik UE (Kublik 2010).

Najczęściej sprowadzane do Polski marki używanych samochodów to Volkswagen, Opel, Renault i Ford, natomiast liderem polskiego rynku sprzedaży nowych samochodów (dane z roku 2010) pozostaje niezmiennie Škoda, a na drugim miejscu jest Fiat. W dalszej kolejności przemiennie plasują się Toyota, Volkswagen, Opel, Renault, Ford i Peugeot. Najchętniej kupowane nowe samochody należą do klasy niższej średniej (Škoda Octavia, Opel Astra, Ford Focus), najdynamiczniej rośnie sprzedaż samochodów terenowo-rekreacyjnych, nie maleje zainteresowanie samochodami kombi i van (Samar 2010.08.19).

Samochody osobowe w Polsce aż w 92,4\% przypadków nie posiadają żadnej gwarancji ani producenta samochodu, ani żadnego serwisu. Średnia wartość samochodu osobowego również jest niewielka i wynosi tylko 11900 zł. Polacy nie osiągają też dużych przebiegów; jest to tylko 15404 km rocznie (Grześkowiak 2007, s. 9).

\section{Warsztaty samochodowe}

W potocznym języku, dla określenia charakteru przedsiębiorstwa serwisującego pojazdy, bardzo popularne i często zamiennie używane są terminy warsztat, stacja lub serwis samochodowy. Z warsztatem samochodowym najczęściej kojarzy się niewielka firma (mały garaż) z jednym stanowiskiem, wyposażona w podstawowe narzędzia i niewiele prostych urządzeń, a z serwisem - duża, wielostanowiskowa stacja obsługi z rozbudowaną infrastrukturą i z wykwalifikowanym 
personelem. Zatem stacje obsługi to takie warsztaty, które charakteryzuje duży przedział liczby stanowisk, od jednego do kilkudziesięciu, wyposażenie oraz zróżnicowany zakres usług, od usług kosmetycznych i konserwacyjnych po naprawy o różnym zakresie. Ze względu na zakres wykonywanych prac obsługowo-naprawczych M. Uzdowski, K.F. Abramek i K. Garczyński dzielą stacje obsługi samochodów na stacje o pełnym zakresie pracy i stacje o ograniczonym zakresie. Stacje o ograniczonym zakresie stanowią najliczniejszą grupę wśród przedsiębiorstw świadczących usługi motoryzacyjne. Dzielą się one na warsztaty specjalistyczne, stacje kontroli pojazdów i stacje szybkiej obsługi (Uzdowski, Abramek, Garczyński 2003, s. 108).

Warsztaty najczęściej specjalizują się w takich tradycyjnych usługach, jak mechanika pojazdowa (szacunkowo ok. 77\% wszystkich warsztatów), blacharstwo i lakiernictwo (30\%), elektrotechnika i elektronika samochodowa (8\%), diagnostyka, serwis ogumienia, obsługa klimatyzacji, tuning, mycie i konserwacja etc. W zależności od wielkości i wyposażenia mogą one posiadać jedno lub więcej stanowisk. Postęp w dziedzinie konstrukcji pojazdów samochodowych i nowe potrzeby klientów ciągle wymuszają na warsztatach rozwój nowych specjalizacji, na przykład w dziedzinie elektroniki, tuningu, telematyki, klimatyzacji, automatycznych przekładni i urządzeń bezpieczeństwa czynnego.

Jeszcze niedawno (10 lat temu) w Polsce na jeden warsztat przypadało ok. 350 samochodów, podczas gdy w Niemczech w tym samym czasie wskaźnik ten był prawie trzykrotnie wyższy. Obecnie proporcje te znacznie się zmieniły, a na jeden statystyczny warsztat w Polsce przypada około 850 samochodów przy średniej niemieckiej 1200 (ryc. 5).

Ryc. 5. Liczba samochodów przypadających na jeden warsztat w Polsce i w Niemczech

\section{Polska $\square$ Niemcy}

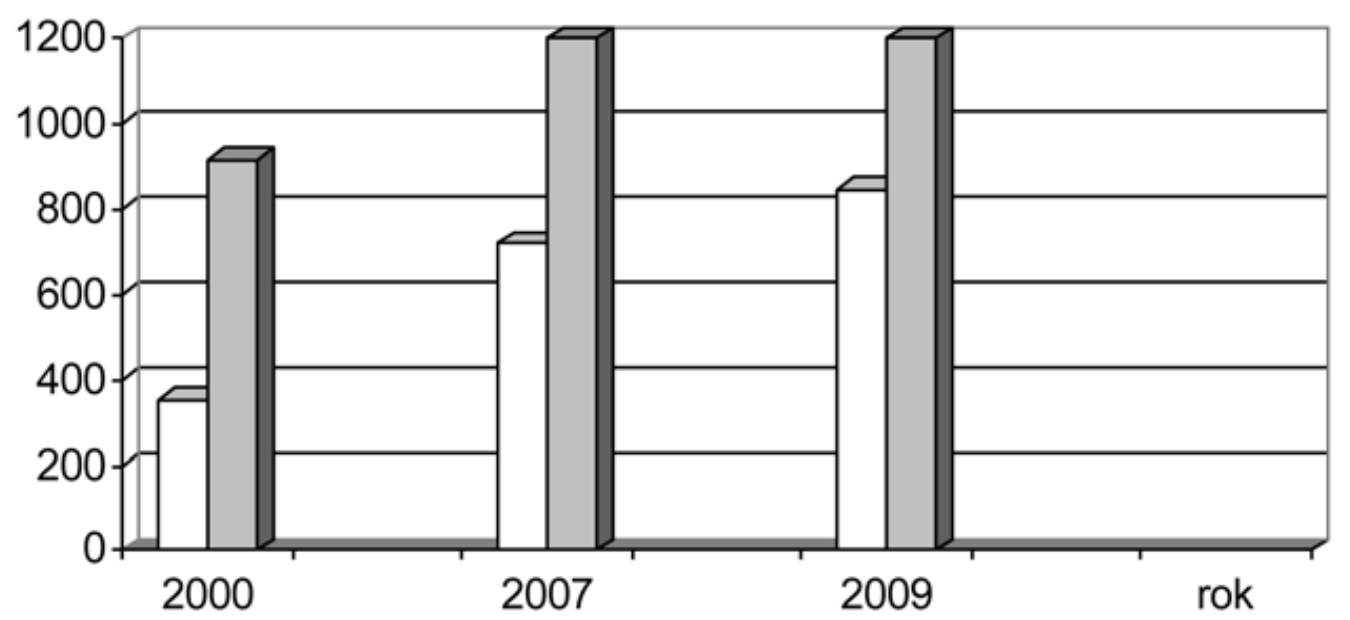

Źródło: opracowanie własne.

Instytut GIPA (GIPA 2003) w badaniach z 2003 r. podzielił grupę warsztatów mechanicznych na małe, średnie i duże. Małe naprawiały po dwa samochody dziennie, średnie - 4, a duże - 7 . Również warsztaty te znacznie różniły się między sobą powierzchnią pomieszczeń i wyposażeniem. W badanej wówczas przez GIPA próbie małe warsztaty mechaniczne były najliczniejsze $(53 \%)$. W kolejnych badaniach prowadzonych przez GIPA w następnych latach została wykazana znaczna redukcja małych warsztatów i zmiana proporcji na rynku napraw na korzyść warsztatów średnich i dużych (ryc. 6). W roku 2007 małe warsztaty stanowiły tylko 22\% całego rynku, średnie $43 \%$, a duże - 35\%. 
Ryc. 6. Zmiany w strukturze warsztatów samochodowych w Polsce w latach 2003-2007

$\square$ warsztaty małe $\square$ warsztaty średnie $\square$ warsztay duże

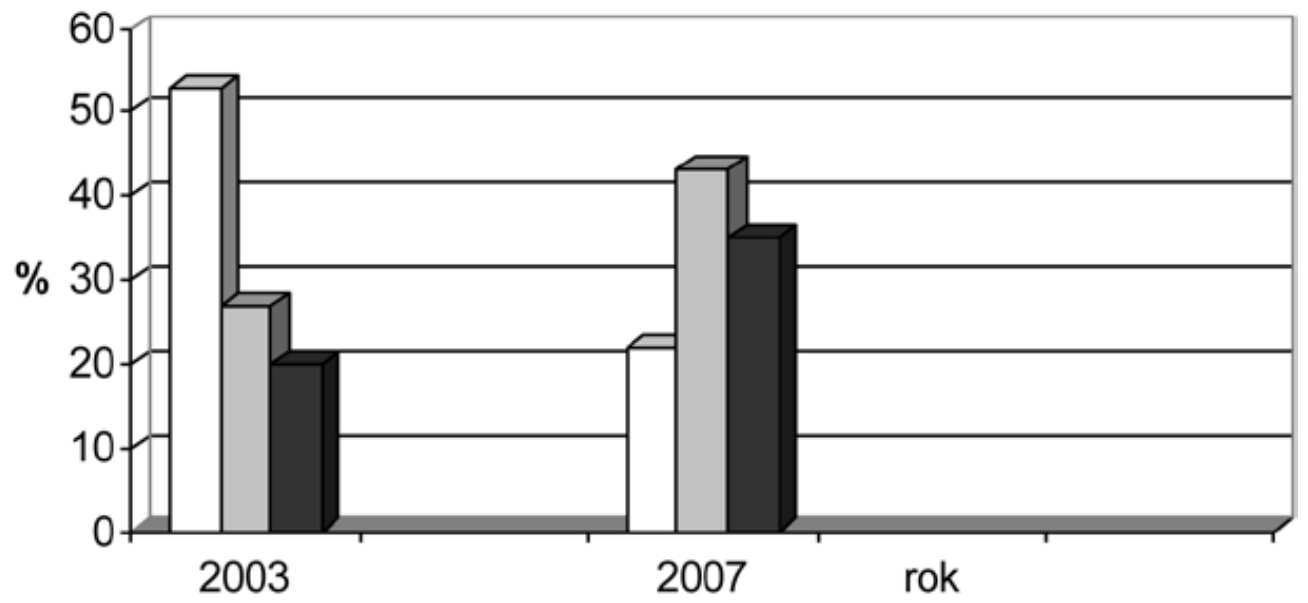

Źródło: opracowanie własne na podstawie GIPA.

W praktyce z powodu dużej różnorodności usług związanych z eksploatacją samochodu podział na małe, średnie i duże dla wszystkich warsztatów z sektora napraw i obsługi samochodów jest niewyraźny i łatwo się zaciera.

Ryc. 7. Liczba warsztatów niezależnych i autoryzowanych przez producentów samochodów w Polsce

\section{$\square$ warsztaty ogółem $\square$ warsztaty niezależne $\square$ warsztaty autoryzowane}

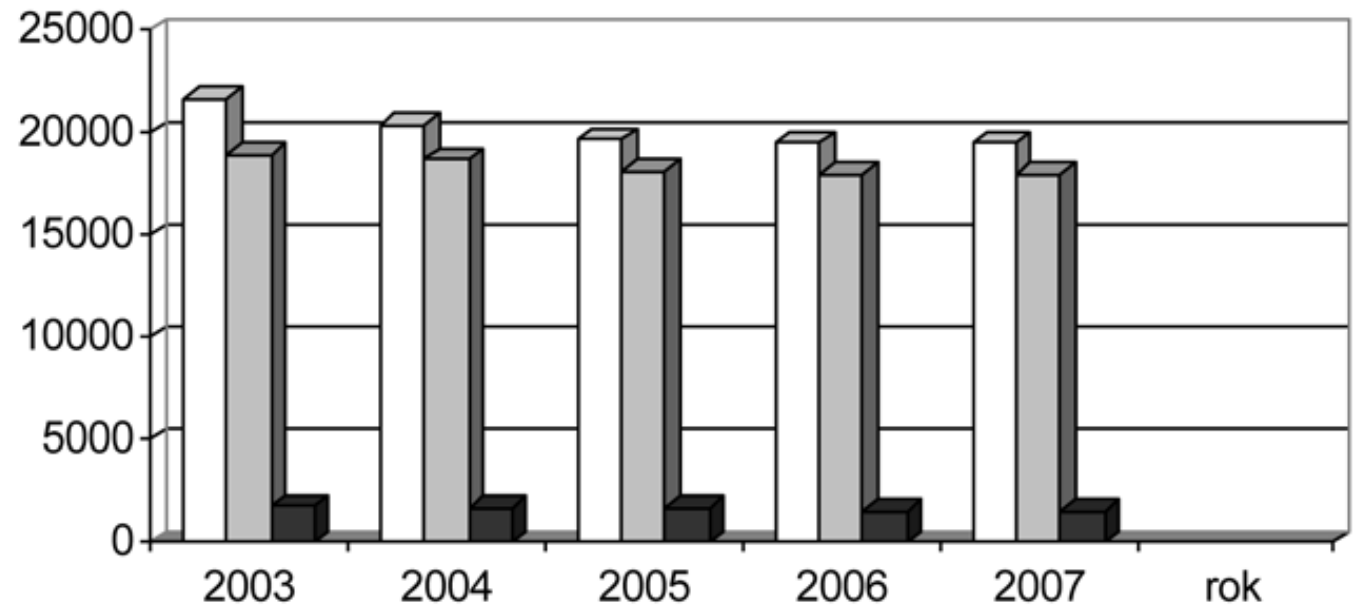

Źródło: opracowanie własne na podstawie GIPA [w:] Soszyński K., Przyszłość polskich warsztatów, http://www.e-autonaprawa.pl/artykuly/67/przyszlosc-polskich-warsztatow.html (stan na dzień 05.09.2009).

Analitycy zajmujący się rynkiem napraw samochodów w Polsce najczęściej dzielą go na warsztaty niezależne, warsztaty autoryzowane przez producentów samochodów (typu dilerskiego) i warsztaty sieciowe. Te ostatnie to warsztaty szybkiej obsługi, firm ubezpieczeniowych lub dużych hurtowni typu kierowniczego, albo warsztaty niezależne, zrzeszone w sieci dystrybutorów i producentów części tzw. właścicielskie. Ponadto na rynku napraw funkcjonują tzw. warsztaty garażowe typu ,zrób to sam”, będące konsekwencją zamiłowania do samodzielnych napraw samochodu i występowania szarej strefy. 
Podział rynku napraw w Polsce jest podobny jak w pozostałych państwach Unii Europejskiej. Istnieją niewielkie i już zanikające różnice wynikające z przeszłości. Na naszym rynku funkcjonują jeszcze sklepy motoryzacyjne sprzedające także części samochodowe, które obsługują samodzielne naprawy garażowe i szarą strefę. W krajach Unii (przed 01.05.2004) znajdowały się również sklepy motoryzacyjne, ale ich oferta obejmowała głównie materiały eksploatacyjne - płyny, oleje, akumulatory - oraz akcesoria - żarówki, dywaniki, foteliki dla dzieci itp. Istotnym wyróżnikiem jest także sposób sprzedaży samochodów używanych; polską specjalnością są giełdy lub autokomisy. W krajach Unii (przed 01.05.2004) najczęstszym miejscem sprzedaży samochodu używanego był diler danej marki lub warsztat, w którym samochód był obsługiwany i naprawiany.

W Polsce tylko do roku 2005 notowany był niewielki spadek liczby warsztatów samochodowych - mimo rosnącego w tym okresie popytu na usługi w zakresie napraw i obsługi samochodów oraz rekordowego importu samochodów używanych w roku 2004 (ryc. 7). Nie było to intensywne zjawisko i dotyczyło przede wszystkim sektora serwisów niezależnych, choć w tym czasie ubywało także i placówek typu dilerskiego, autoryzowanych przez producenta. Inaczej było w Niemczech, gdzie wyraźnie zmniejszała się liczba punktów serwisowych, zarówno autoryzowanych, jak i niezależnych (ryc. 8). Zapewne w obu przypadkach działo się tak dlatego, że nierentowne warsztaty opuszczały rynek, a te pozostające na nim zwiększyły swój potencjał głównie przez wzrost liczby stanowisk warsztatowych. Charakterystyczną cechą dla rynku niemieckiego jest wysoka proporcja (1:1) warsztatów autoryzowanych w stosunku do warsztatów niezależnych (ryc. 8). W Polsce proporcja ta jest dziesięciokrotnie mniejsza (1:12; por. ryc. 7).

Ryc. 8. Liczba warsztatów niezależnych i autoryzowanych przez producentów samochodów w Niemczech

warsztaty ogółem $\square$ warsztaty niezależne $\square$ warsztaty autoryzowane

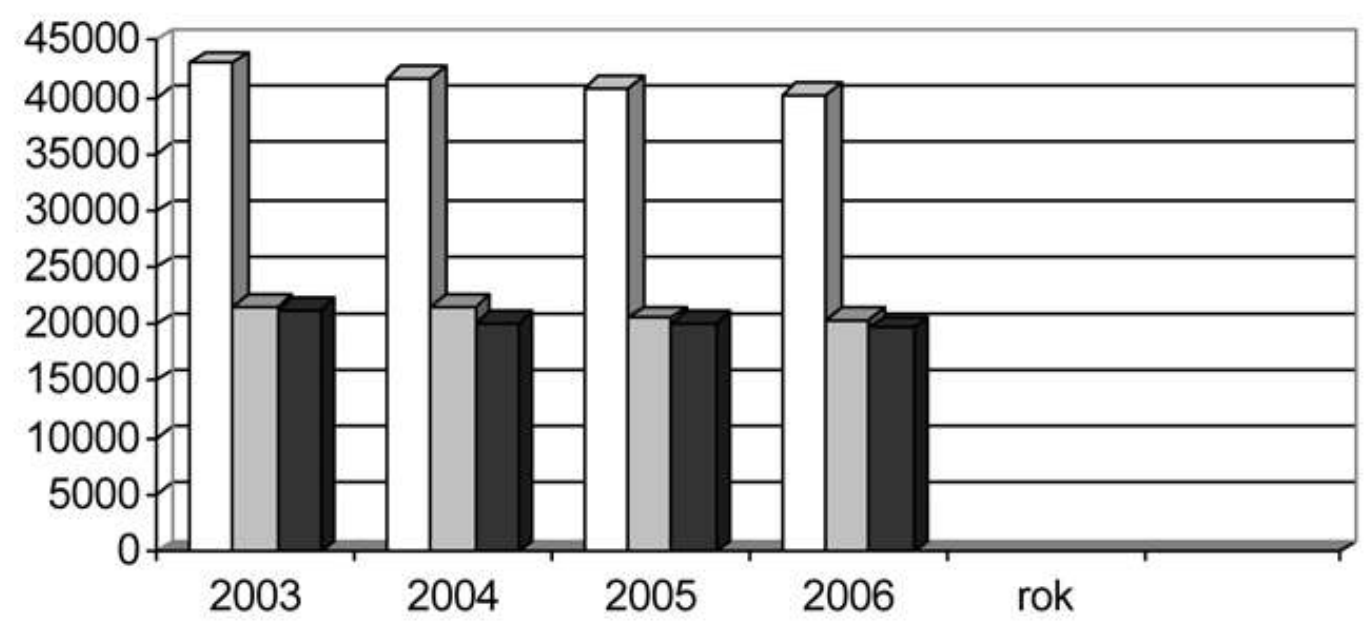

Źródło: opracowanie własne na podstawie Automobilwoche [w:] Soszyński K., Przyszłość polskich warsztatów, http://www.e-autonaprawa.pl/artykuly/67/przyszlosc-polskich-warsztatow.html (stan na dzień 05.09.2009).

Współcześnie szczególnego znaczenia nabierają nowe formy organizacyjne określane mianem przedsiębiorstw sieciowych. Koncepcja sieci warsztatowej jest rezultatem połączenia zalet wynikających z funkcjonowania niezależnych warsztatów z wysokim poziomem świadczonych usług. Składają się na to: wyposażenie specjalistyczne i kompetencje pracowników 
gwarantujące obsługę na wysokim poziomie jakościowym z użyciem oryginalnych części, bliskość warsztatu, szybkość wykonania naprawy i przystępna cena usługi. Niektórzy analitycy (Szczepaniak 2006) rynku motoryzacyjnego uważają, że zjednoczone pod jednym szyldem warsztaty to przyszłość dla niezależnego sektora napraw samochodów zwłaszcza, że doświadczenia europejskie i dotychczasowe doświadczenia polskie pokazują, że warsztaty zorganizowane w sieci mają niekwestionowaną przewagę nad warsztatami niezależnymi w pozyskiwaniu nowych klientów. Wprawdzie w Polsce notuje się zainteresowanie sieciową formą działalności, a w roku 2007 w porównaniu z rokiem 2006 liczba uczestników sieci warsztatowych wzrosła o 10\%, ale udział ten nadal jest niezadowalający. Obecnie w Polsce udział niezależnych warsztatów samochodowych w sieciach jest niewielki (ok. 19\%) i o wiele mniejszy niż w Niemczech (ryc. 9).

Ryc. 9. Odsetek warsztatów niezależnych należących do sieci

\section{Polska $\square$ Niemcy}

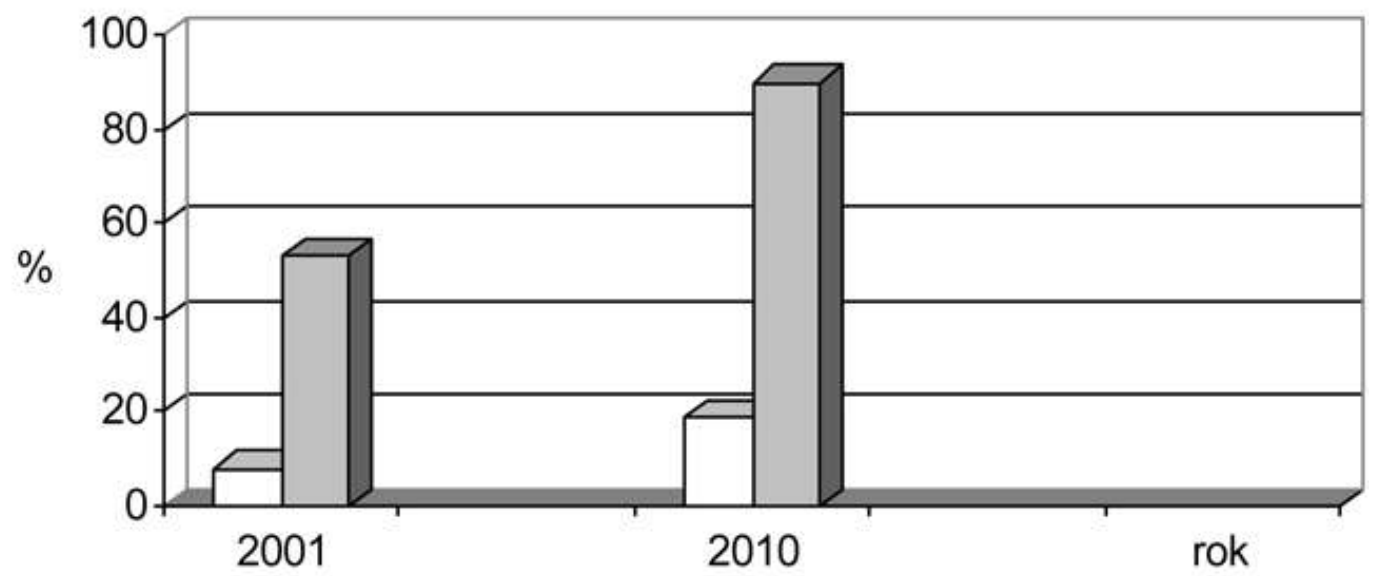

Źródło: opracowanie własne na podstawie Motofocus, GIPA i Bosch.

Sondaż przeprowadzony wśród niezależnych warsztatów (Franke 2009) wskazuje, że w Polsce aż 37\% właścicieli warsztatów samochodowych nie zamierza związać się z siecią warsztatową. Dla blisko 30\% warsztatów zagadnienie to jest w obrębie rozważań, co może oznaczać, że są to potencjalni kandydaci do sieci warsztatowych. Istnieje także duża grupa warsztatów, która decyzję o przystąpieniu do sieci warsztatowej już podjęła i albo już podpisała umowę partnerską, albo zamierza to zrobić w najbliższym czasie. O pozytywnych, ale zbyt powolnych przemianach $w$ postawach warsztatów w sprawie przynależności do sieci świadczy porównanie z wynikami, które uzyskano z badań przeprowadzonych w 2003 r. (GIPA, 12.2003). Wówczas ponad $84 \%$ polskich warsztatów w ogóle nie planowało przyłączać się do jakiejkolwiek sieci. Najczęściej były to duże warsztaty (ponad 92\%), rzadziej małe (ok. 87\%), a najrzadziej średnie (ok. 73\%).

\section{Zachowania właścicieli samochodów}

Zachowania właścicieli samochodów w Polsce trafnie obrazują badania z 2005 r. Kto naprawia nasze auta? Wynika z nich, że pięć lat temu niemal jedna trzecia Polaków (32\%) odpowiedzialnych za naprawy samochodu w gospodarstwie domowym samodzielnie wykonywała czynności związane z bieżącą konserwacją i serwisowaniem samochodu. Dla pozostałych najpopularniejszym miejscem dokonywania takich napraw były warsztaty niezależne (nieautoryzowane), 
które odwiedzało 38\% respondentów i warsztaty autoryzowane przez producentów, gdzie tylko $26 \%$ badanych zlecała bieżące naprawy. Inaczej było w przypadku napraw powypadkowych, które są dokonywane zwykle przez specjalistów: 32\% badanych powierzało je warsztatom niezależnym, zaś $20 \%$ warsztatom autoryzowanym. Tylko $6 \%$ badanych decydowało się na samodzielną naprawę samochodu po wypadku. Natomiast blisko jedna trzecia $(32 \%)$ osób decydujących o miejscu dokonania naprawy nie potrafiła określić, komu zleciłaby naprawę w razie takiej potrzeby (ryc. 10).

Ryc. 10. Miejsce dokonywania naprawy samochodu

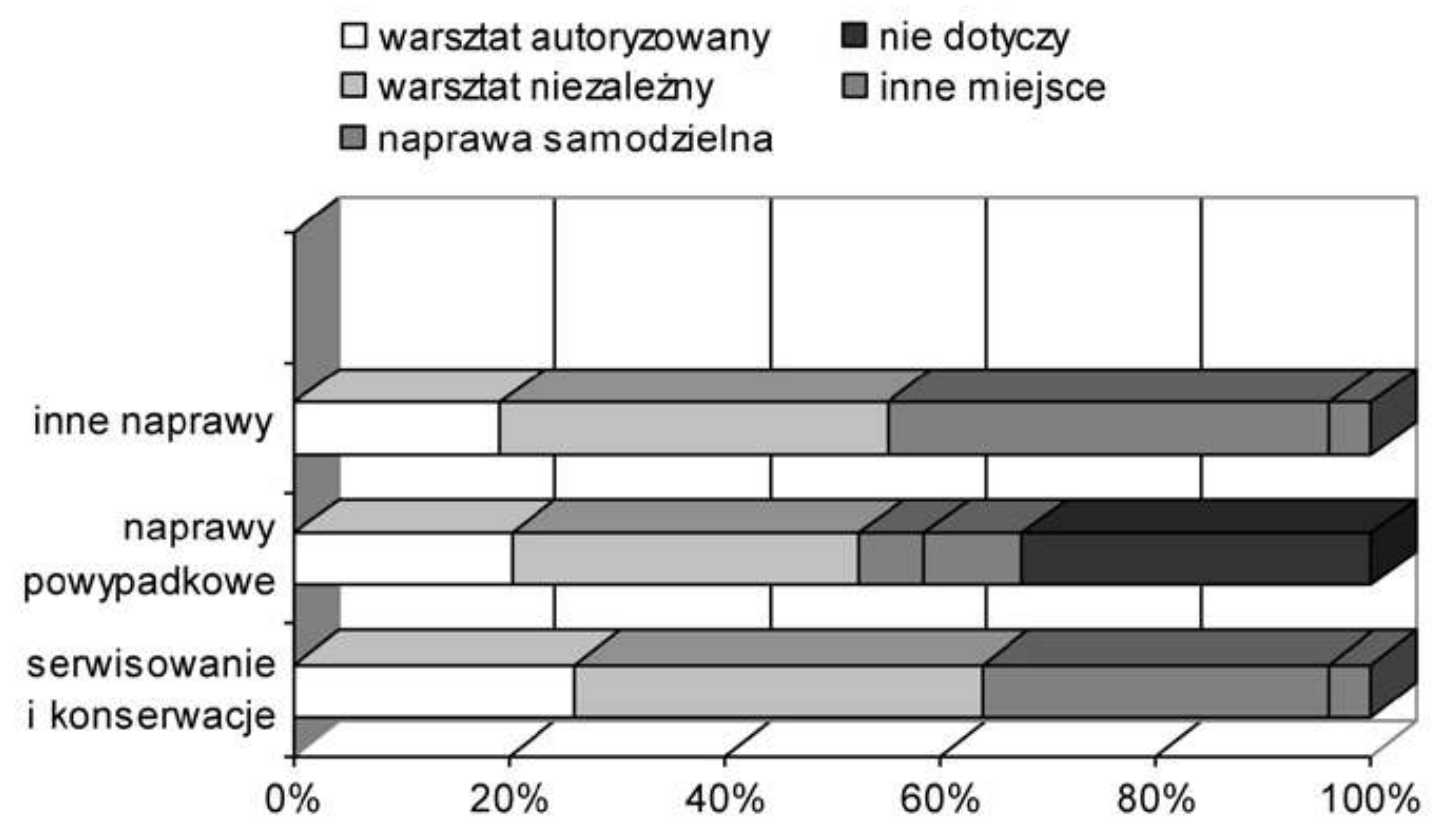

Źródło: opracowanie własne na podstawie badania Kto naprawia nasze auta?, www.tns-global.pl (stan na dzień 01.08.2006).

Inne naprawy, czyli wszelkie prace przy samochodzie poza bieżącą konserwacją i naprawami powypadkowymi, były najczęściej (przez 41\% respondentów) wykonywane samodzielnie (w tym także z pomocą rodziny bądź znajomych). Warsztaty niezależne wybierało wtedy $36 \%$ osób, natomiast na serwisy autoryzowane decydowała się blisko co piąta osoba (19\%) odpowiedzialna w domu za naprawy.

Obecnie ze względu na wzrastający stopień zaawansowania technologicznego we współczesnych samochodach udział napraw dokonywanych samodzielnie w Polsce systematycznie maleje, ale nadal jest wyższy niż w takich krajach europejskich, jak Niemcy czy Francja. Najczęściej sami naprawiają swoje samochody ludzie młodzi, rolnicy i taksówkarze, a zamiłowanie do samodzielnego naprawiania wynika z potrzeby oszczędności i występuje jeszcze dość często w uboższych regionach Polski. Na przykład w Warszawie wymiana klocków hamulcowych odbyłaby się w serwisie (Profi Auto 2010, wnp.pl). Polacy także rzadziej korzystają z usług autoryzowanych warsztatów. Powodem są nie tylko ceny usług w warsztatach, ale także wiek polskich samochodów, gdyż w większości kupujemy używane samochody, co znalazło potwierdzenie w badaniu Intencja zakupu samochodu 2010. Z badania tego wyraźnie widać, że w zdecydowanej większości (89-91\%) Polacy kupują samochody używane, a tylko niewielka grupa (11-19\%) decyduje się na zakup samochodu fabrycznie nowego. Zatem duża liczba samochodów używanych, kupowanych przez Polaków, adekwatny do wieku stan techniczny tych samochodów i ich niewielka wartość pocią- 
gają za sobą popyt na usługi w zakresie napraw samochodowych i tym samym określone wydatki na obsługę i naprawy (ryc. 11). Wydatki te w 2006 r. wynosiły łącznie 665 zł na jeden statystyczny samochód, gdy w tym samym okresie Niemcy przeznaczali na obsługę i naprawę samochodu równowartość 1548 zł. Różna jest też struktura tych kwot: u nas znacznie więcej wydaje się na naprawy niż na systematyczną obsługę, w Niemczech natomiast odwrotnie. W Polsce aż 55\% właścicieli samochodów udaje się do warsztatu dopiero w wypadku awarii, a tylko 45\% działa prewencyjnie (Kierzek 2007, s. 6), systematycznie wykonując przeglądy techniczne. Należy jednak przypuszczać, że te dysproporcje będą się z czasem wyrównywać, gdyż w ostatnich latach rośnie liczba użytkowników samochodów, którzy prewencyjnie przyjeżdżają do warsztatów, a nie tylko wtedy, kiedy pojawia się uszkodzenie. Przyczyną tego jest przede wszystkim wzrost zaleceń obsługowo-naprawczych we współczesnych samochodach, wysokie ceny zespołów koniecznych do późniejszej wymiany i tym samym zwiększona świadomość eksploatacyjna polskich kierowców. Fakt, że na regularną kontrolę stanu technicznego pojazdów i czynności prewencyjne wydawać będziemy coraz więcej, nie pozostanie bez wpływu również na asortyment i jakość oferowanych przez warsztaty usług i jest to prognoza pomyślna dla warsztatów.

Ryc. 11. Wydatki na naprawy i serwis samochodów w Polsce i w Niemczech

$\square$ obsługa $\square$ naprawa $\square$ obsługa i naprawa razem

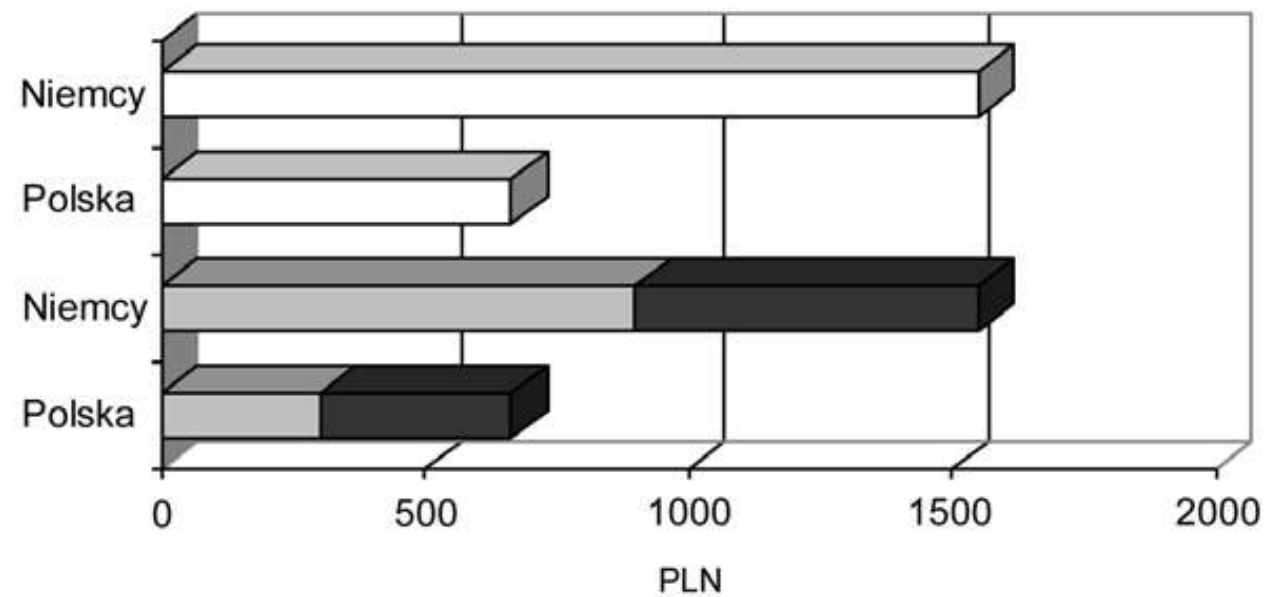

Źródło: opracowanie własne na podstawie ATR, GIPA [w:] Soszyński K., Przyszłość polskich warsztatów, http://www.e-autonaprawa.pl/artykuly/67/przyszlosc-polskich-warsztatow.html (stan na dzień 05.09.2009).

\section{Warsztaty w warunkach postępującej globalizacji gospodarki}

Nie bez znaczenia dla warsztatów samochodowych, jak i dla całej branży motoryzacyjnej pozostają zjawiska gospodarcze, społeczne i polityczne, które obejmują swym zasięgiem wiele państw i są powiązane z szeroko rozumianym procesem globalizacji gospodarki. Proces ten warunkują: rozwój technicznych środków komunikacji, liberalizacja handlu międzynarodowego i redukcja barier przepływu towarów i kapitału (Winiarski 2006, s. 177); sprzyjają temu m.in. korzystne warunki polityczne (odpowiedni klimat) i działalność organizacji światowych, np. MFW, WTO itd. (ryc. 12). Globalizacja jest procesem intensywnym i niemożliwym do zahamowania. Ma ona wiele ujęć oraz definicji, a rozwija się dzięki silnym dążeniom społeczeństw do lepszego życia, przede wszystkim dzięki rozwojowi nowoczesnych technik i technologii. Najpowszechniejsze definicje globalizacji to ujęcia w rozumieniu uniwersalizmu, internacjonalizacji i liberalizacji (Micał 2008, s. 152). 
Ryc. 12. Uwarunkowania i czynniki sprzyjające procesowi globalizacji w branży motoryzacyjnej

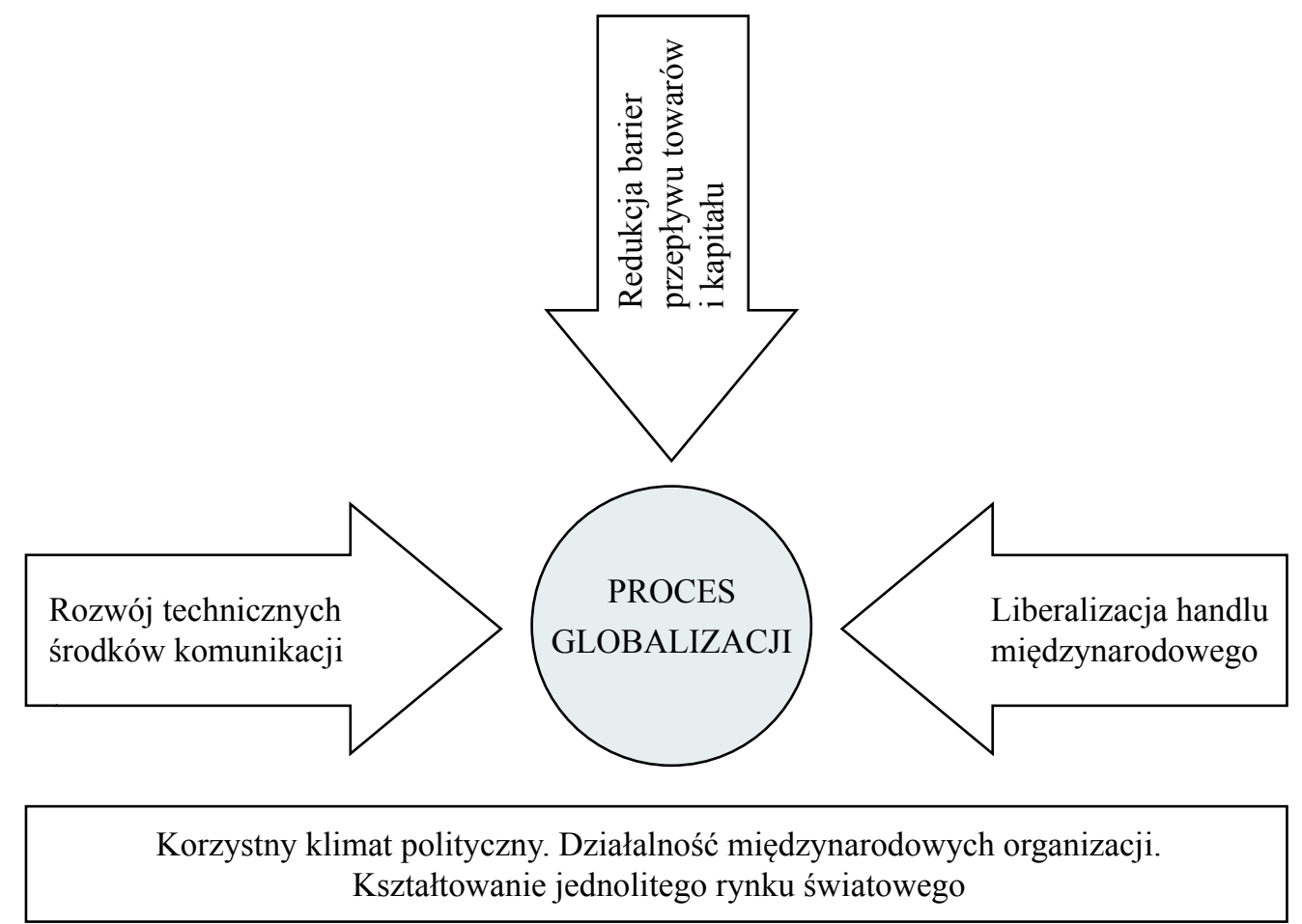

Źródło: opracowanie własne na podstawie definicji globalizacji.

Najwięcej przykładów uniwersalizmu w branży motoryzacyjnej dostarczają rozwiązania konstrukcyjne współczesnych samochodów, ich podatność naprawcza i technologie serwisowe. Internacjonalizacja odnosi się do wzrostu wymiany handlowej pomiędzy państwami i wzrostu zależności podmiotów uczestniczących w handlu. Motoryzacja przyciąga wielkie inwestycje zagraniczne, tak jak ma to miejsce w Polsce. Montaż samochodów odbywa się na różnych kontynentach, a podzespoły stosowane do montażu produkowane są na całym świecie. Na całym świecie dominują też te same marki i modele samochodów wymagające podobnego serwisowania i podobnych napraw. W sektorze warsztatów jest coraz więcej zależności i powiązań nie tylko na szczeblach lokalnych, ale także i w skali międzynarodowej. Widać to szczególnie wyraźnie w sektorze warsztatów autoryzowanych i w sektorze warsztatów zrzeszonych w międzynarodowych sieciach. Celem liberalizacji jest budowanie gospodarki światowej bez granic, gdyż globalizacja wiąże się z procesem międzynarodowej integracji gospodarczej (likwidacji barier w handlu międzynarodowym, ograniczeń transferów kapitałowych). To właśnie m.in. liberalizacja zapoczątkowała masowy import do Polski używanych samochodów i tym samym wzrost zapotrzebowania na usługi warsztatowe. Prawie od podstaw powstało wiele warsztatów przygranicznych nastawionych wyłącznie na obsługę importowanych samochodów. Liberalizacja wymaga także stanowienia odpowiedniego prawa. Konieczne są regulacje w zakresie części zamiennych, napraw oraz serwisu samochodów. 
Tab. 1. Przykładowe zmiany na rynku i w otoczeniu warsztatów w wyniku procesu globalizacji w branży motoryzacyjnej

\begin{tabular}{|c|l|l|}
\hline Lp. & \multicolumn{1}{|c|}{$\begin{array}{c}\text { Zmiany na rynku } \\
\text { i w otoczeniu warsztatów }\end{array}$} & \multicolumn{1}{|c|}{ Przykłady zmian } \\
\hline 1 & $\begin{array}{l}\text { Konsolidacja rynku napraw } \\
\text { i sprzedaży samochodów } \\
\text { oraz części }\end{array}$ & $\begin{array}{l}\text { Rosnący udział warsztatów niezależnych w sieciach, } \\
\text { łączenie się dilerów samochodowych, scalanie na rynku } \\
\text { serwisu opon - Fleet Serwis, Spółka Orzeł }\end{array}$ \\
\hline 2 & $\begin{array}{l}\text { Demonopolizacja prawa } \\
\text { do naprawy - informacji } \\
\text { technicznej i dostępu } \\
\text { do części zamiennych }\end{array}$ & $\begin{array}{l}\text { Zmiany w uregulowaniach prawnych, np. rozporządzenie UE } \\
\text { w sprawie porozumień wertykalnych i praktyk uzgodnionych } \\
\text { w sektorze pojazdów silnikowych, duży udział tanich części } \\
\text { pochodzących z krajów Dalekiego Wschodu }\end{array}$ \\
\hline 3 & $\begin{array}{l}\text { Zmiany w postrzeganiu } \\
\text { bezpieczeństwa - samo- } \\
\text { chód bezpieczny dla } \\
\text { użytkowników i przyjazny } \\
\text { środowisku naturalnemu }\end{array}$ & $\begin{array}{l}\text { Odmładzanie parku samochodowego, nacisk na prewencję, } \\
\text { samochody z napędem alternatywnym (e-samochody), nacisk } \\
\text { na recykling materiałowy i produktowy, wzrost udziału } \\
\text { w naprawach części regenerowanych, wysoki udział technolo- } \\
\text { gii IT, rozwój telematyki, eliminacja patologii w sektorze SKP }\end{array}$ \\
\hline 4 & $\begin{array}{l}\text { Wzrost wskaźnika } \\
\text { motoryzacji }\end{array}$ & $\begin{array}{l}\text { Zwiększenie zapotrzebowania na profesjonalne usługi } \\
\text { serwisowe, malejąca liczba małych warsztatów, większy udział } \\
\text { warsztatów dużych, zwiększenie wydatków na utrzymanie } \\
\text { samochodu }\end{array}$ \\
\hline 5 & $\begin{array}{l}\text { Zmiany w postrzeganiu } \\
\text { zasobów niematerialnych } \\
- \text { warsztat jako organizacja } \\
\text { inteligentna i stale się } \\
\text { ucząca }\end{array}$ & $\begin{array}{l}\text { Wzrost zapotrzebowania na aktualną wiedzę i informację, } \\
\text { przyrost liczby modeli i krótszy cykl życia samochodu, } \\
\text { tendencja do wydłużania resursów obsługowych, postęp } \\
\text { w konstrukcji zespołów, zapotrzebowanie na wykwalifikowaną } \\
\text { kadrę }\end{array}$ \\
\hline obsługi klientów & $\begin{array}{l}\text { Poszerzanie zakresu usług, wzrost mobilności serwisu, } \\
\text { pośrednictwo w zakupie i w odsprzedaży samochodu, jednolite } \\
\text { standardy, ewidencja historii napraw, płatności bezgotówkowe, } \\
\text { samochód zastępczy }\end{array}$ \\
\hline
\end{tabular}

Źródło: opracowanie własne.

Najważniejsze zmiany na rynku i w otoczeniu warsztatów, które niesie ze sobą globalizacja gospodarki, dotyczą konsolidacji rynku napraw i sprzedaży samochodów, demonopolizacji prawa do naprawy ${ }^{3}$, zmian w postrzeganiu bezpieczeństwa, przyrostu liczby samochodów, zmian w postrzeganiu zasobów niematerialnych przez warsztaty oraz zmian w procesach obsługi klientów. Przedstawiono to w tabeli 1, z której wynika, że przed polskimi warsztatami

${ }^{3}$ Rozporzadzenie Komisji (UE) Nr 461/2010 z dnia 27 maja 2010 r. w sprawie stosowania art. 101 ust. 3 „Traktatu o funkcjonowaniu Unii Europejskiej” do kategorii porozumień wertykalnych i praktyk uzgodnionych w sektorze pojazdów silnikowych 
samochodowymi stoi wiele nowych i trudnych do natychmiastowej realizacji wyzwań. Są to: powiększanie liczby stanowisk obsługowo-naprawczych, a tym samym poszerzanie zakresu usług i zakupy nowego sprzętu, przystępowanie do sieci warsztatowych i współpraca międzynarodowa, uczestnictwo w sektorze napraw mobilnych, stałe lobbowanie na rzecz zmian $\mathrm{w}$ prawie sprzyjających niezależnemu rynkowi, uczestnictwo w procesie recyklingu nie tylko poprzez propagowanie części regenerowanych, ale i aktywne uczestnictwo w odzysku elementów samochodu i innych materiałów powtórnego użytku, stałe doskonalenie umiejętności, pozyskiwanie wiedzy i informacji o nowych rozwiązaniach technologicznych w konstrukcji samochodów, np. przygotowanie się do wzrastającego udziału napędów niekonwencjonalnych (napęd elektryczny, tzw. e-napęd), uczestnictwo w rynku sprzedaży lub zamiany samochodów, ujednolicenie standardów obsługi klienta i warunków gwarancji za naprawy oraz zapewnienie klientowi kompleksowych usług.

Najbliższe dziesięciolecie w wyniku potęgujących się procesów globalizacji powinno przynieść radykalne zmiany na rynku, także w serwisowaniu samochodów w Polsce. Rosnąca świadomość społeczna w zakresie ochrony środowiska naturalnego i konieczność spełnienia coraz surowszych norm ekologicznych doprowadzą do istotnych zmian organizacyjnych i technologicznych w skali globalnej. Można oczekiwać, że branża motoryzacyjna będzie wśród liderów tych zmian. Rynek napraw samochodów w Polsce dysponuje dużymi rezerwami i nie wykorzystuje w pełni swoich możliwości techniczno-organizacyjnych. Porównanie Polski z krajami wysoko rozwiniętymi wskazuje na szanse naszego kraju w utrzymaniu stabilnego rozwoju branży motoryzacyjnej, gdyż w miarę wzrostu stopy życiowej następuje zwiększenie udziału usług określane jako serwicyzacja gospodarki, a siłą napędową tego zjawiska są potrzeby konsumentów.

\section{Literatura}

1. Badanie kanałów dystrybucji, 2003, materiały niepublikowane, GIPA.

2. Franke A., 2009, Warsztat w sieci czy poza siecia, http://www.motofocus.pl/raport/raport_4200.php (stan na dzień 25.07.2009).

3. Grześkowiak R., 2007, Szybkie spojrzenie na polski rynek motoryzacyjny, „Wiadomości Inter Cars SA", nr 23, Warszawa.

4. Import samochodów używanych w marcu, 2010, Moto Onet.pl, http://moto.onet.pl/1609486,1,import-samochodow-uzywanych-w-marcu,artykul.html?node $=8$ (stan na dzień 19.08.2010).

5. Kierzek R.K., 2007, Rynek wybrat wolność, ,Wiadomości Inter Cars SA”, nr 23, Warszawa.

6. Koch K., 2004, Rynek sprzedaży w 2003 r., „Automotoserwis”, nr 7-8, Warszawa.

7. Kto naprawia nasze auta?, badania na temat eksploatacji i napraw samochodów osobowych przeprowadzone przez TNS OBOP i TNS Infratest w 2005 roku, www.tns-global.pl (stan na dzień 01.08.2006).

8. Kublik A., 2010, Polska potrzebuje pót wieku, by wymienić stare auta na nowe, Gazeta.pl http://m. wyborcza.pl/wyborcza/1,105226,8433599,Polska_potrzebuje_pol_wieku_by_wymienic_stare_auta. html ( stan na dzień 28.09.2010).

9. Maty rocznik statystyczny Polski 2010, 2010, GUS, Warszawa.

10. Micał M., 2008, Proces globalizacji we wspótczesnym świecie, „Zeszyty Naukowe Zakładu Europeistyki Wyższej Szkoły Informatyki i Zarządzania w Rzeszowie”, nr 3/(8), Rzeszów.

11. Polacy chętnie sami naprawiaja swoje samochody, 2010, ProfiAuto, wnp.pl (stan na dzień 25.08.2010).

12. Transport-wyniki działalności w 2008 roku, 2009, GUS, Warszawa. 
13. Intencja zakupu samochodu 2010, badania OMNIMAS przeprowadzone przez TNS OBOP w okresie 21 stycznia - 7 lutego 2010, www.tns-global.pl (stan na dzień 18.08.2010).

14. Sprzedaż nowych samochodów w lipcu 2010, 2010, http://www.samar.pl/_ / _la/pl/_ac/sec,4/ new/59049/_SAMAR-Sprzeda\%C5\%BC-nowych-samochod\%C3\%B3w-osobowych-w-lipcu-2010. html (stan na dzień 19.08.2010).

15. Najchętniej kupowane auta to niezmiennie klasa niższa średnia, 2010, http://www.samar.pl/index. $\mathrm{html}$ ? la $=\mathrm{pl} \& \_\mathrm{ac}=\mathrm{sec}, 4 \&$ new $=59185$ (stan na dzień 19.08.2010).

16. Soszyński K., 2009, Przyszłość polskich warsztatów, 2009, http://www.e-autonaprawa.pl/artykuly/67/ przyszlosc-polskich-warsztatow.html (stan na dzień 05.09.2009).

17. Szczepaniak M., 2006, Sieci serwisowe w Polsce, http://www.autofirmowe.pl/5696,sieci_serwisowe. html (stan na dzień 15.07.2009).

18. Uzdowski M., Abramek K.F., Garczyński K., 2003, Pojazdy samochodowe. Eksploatacja techniczna i naprawa, WKiE, Warszawa.

19. Winiarski B., 2006, Polityka gospodarcza w obliczu procesów globalizacji. Perspektywy na pierwsze dziesięciolecia XXI wieku [w:] Polityka gospodarcza, B. Winiarski (red.), Wyd. 3, Wydawnictwo Naukowe PWN, Warszawa.

\section{Car Workshops in the Conditions of Globalization}

The subject of paper is the issue of car service market in Poland. The development and organizational structure of car service has been presented. The main differences in car service in Poland and Germany have been pointed out. Discussion on global changes in economy linked to the car service market was undertaken. 